\title{
Rādhe, Rādhe!: Continuity and Change in the Contemporary Oral Performance of the Bhāgavatapurāna
}

\author{
MCCOMAS TAYLOR ${ }^{1}$ \\ The Australian National University \\ School of Culture, History and Language \\ Baldessin Precinct Building; Australian National University \\ ACT 0200 Australia \\ mccomas.taylor@anu.edu.au
}

\begin{abstract}
This article focuses on the sacred week-long story-telling event known as a Bhāgavat-saptāh. The saptāh centres on narratives of the deity Viṣnu and, in particular, his manifestation as Kṛ̦ṇa, and on Kṛșna's devoted lover Rādhā. These stories are preserved in their most authoritative form in the Sanskrit text of the Bhāgavatapurāna. First I will examine the traditional instructions for holding a saptāh, which I will call the 'archetype'. I will then describe a saptāh which took place at Vrindavan, Uttarpradesh, India, in November 2009. I will then compare the archetype with the case study, identifying six major continuities: the central role of the text, temporal aspects, economic considerations, visual preparation, spatial arrangements and social inclusiveness. I also identify two major divergences: the sectarian content and the use of the vernacular. Finally, I seek to explain both in terms of modernizing processes. Continuity and divergence are found to take place both in spite of, and because of, such processes.
\end{abstract}

KEYWORDS: Bhāgavatapurāną; Bhāgavat-saptāh; Kṛșna; oral performance; Rādhā; Vrindavan.

\section{INTRODUCTION}

Vrindavan is a town of about 60,000 inhabitants situated four hours by road southeast of Delhi in the state of Uttarpradesh. ${ }^{2}$ It lies at the heart of the

1. McComas Taylor heads the South Asia Program in the School of Culture, History and Language, College of Asia and the Pacific at the Australian National University. His research focuses on power and knowledge in Sanskrit texts and the contemporary purānic performance.

2. I use standard modern Hindi spellings for names, words and phrases usually encountered in that language, and the Sanskrit forms of words when this is the more usual form. 
district known as Braj, where the deity Kṛṣna is said to have been born and raised, and where the famous events of his youth are supposed to have taken place. For this reason, it is an important centre of worship and pilgrimage.

In November 2009, the dusty streets of Vrindavan were festooned with brilliant banners and posters advertising seven-day cycles of story-telling based on the Bhägavatapurāna, known as Bhägavat-saptāh. Some banners were produced with the latest large-scale laser printing technology; others were hand-painted canvases strung up on power-poles. Yet others were modest handbills pasted on walls. The divine faces of the main narrators-to-be, often ringed by a nimbus of sacred light, smile down benignly from these advertisements onto the tangle of traffic below. A quick survey revealed that the many hundreds of posters were promoting nearly 20 separate saptāh events. Some were relatively modest affairs to be held in a local ashram and run on a limited budget. At the other end of the scale were lavish affairs, including even a saptāh-cum-luxury cruise to Thailand, Malaysia and Singapore.

While much has been written on the religious, philosophical and literary aspects of the Bhägavatapurāna as a text, little or nothing has been written on the Bhägavat-saptā $h^{3}$ as a contemporary tradition which is a lively and significant aspect of religious life in Northern India. I will begin this article by introducing the Bhāgavatapurāna. I will then summarize the traditional instructions for the organization of a seven-day event, which I call the 'archetype'. This is followed by the description of a saptāh in which I was a participant-observer (Spradley 1980). I also draw on several other saptāhs for which I have partial data. I then consider the continuities and the differences between the archetype and the case study. In the conclusion, I will reflect on the impact of modernity on the institution.

The Bhāgavatapurāna is devoted to the deity Viṣnu, and most significantly, to his avatar as Lord Kṛșna. It is the major normative textual source for countless millions of devotees (bhaktas) of Kṛșna throughout India and among the Indian diaspora. The tenth book of the Bhāgavatapurāna, which accounts for almost one third of its total length, recounts the youthful pastimes (lī $\bar{a})$ of Kṛṣna among the cow-herding people of the region known as Vraja in Sanskrit (Vraj or Braj in Hindi). Scholarly consensus holds that the text reached its current form at about the end of the first millennium CE. Many stories about Kṛ̣na appear in their most authoritative form in the Bhāgavatapurāṇa: taking the curds, overturning the cart, uprooting the two Arjuna trees, destroying demons, stealing the cow-herd girls' clothes, and so on. The love of the cow-herd maidens for the handsome youth is a powerful metaphor for the purest and highest form of love (Hindi: śuddh prem) that an individual may experience.

The best summaries of the Bhägavatapurāna are by Rocher (1986) and Bryant (2007). Goswami (BhP 2005) gives an accurate version of the complete Sanskrit

3. I use the standard Hindi form of name of this event, as this is invariably used in India.

(c) Equinox Publishing Ltd 2012.

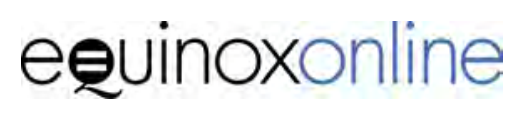


text with a serviceable if quaint English translation. On the pastimes of Kṛṣna, see Schweig (2007b) and especially a new translation by Bryant (2004).

\section{THE ARCHETYPE}

According to the Bhägavatapurāna itself, the text was first related in the course of seven days by the sage Śuka to the king Parīkșit as the latter lay waiting to die as the result of a curse. Having heard the narrative, the king achieved liberation (mokșa) at the very moment of his death. Accordingly, reading or hearing the Bhāgavatapurāna over a seven-day period has attained special significance. This practice is known in Sanskrit as a Bhāgavata-saptāha ('Bhāgavata-week'), or simply in Hindi as a saptāh. Traditionally, a saptāh is said to confer liberation on the sponsor (Skt. yajamāna, H. yajmān) and the audience. In its contemporary form, the reasons given for holding a saptāh include seeking liberation for deceased relatives and forebears.

How is a saptāh to be carried out? A comprehensive set of instructions is given in the sixth chapter of the Uttarakhanda of the Padmapurāna, in a section called the Srimad-bhāgavata-māhātmya ('The greatness of the glorious Bhāgavata[purāna]'). This chapter is also included in modern editions of the Bhāgavatapurāna (BhP 0.6). In the following section, I will summarize these instructions, as this will provide a benchmark with which to compare contemporary practice.

The instructions will be considered in three parts: first, the preparations; second, the actual event and the conduct of participants; and third, the followup activities including remuneration and the giving of gifts. Starting with the preparations, an astrologer should be invited to nominate an auspicious day for the commencement of the saptāh. The Indian months of Bhādrapada, Āśvina, Kārtika, Mārgaśirṣa, Āṣạ̣̄ha and Śrāvaṇa (corresponding roughly to August-November, and June-July) are considered most suitable. The sponsor is advised to set aside as much money for a saptāh as he would for a wedding (BhP 0.6.2). A saptāh is a significant undertaking, demanding of both time and resources, so 'others, too, who are industrious, should be enlisted as one's associates in this undertaking' (BhP 0.6.4).

Once the time and date for the saptāh have been determined, invitations should be sent far and wide. The instructions specifically mention promoting the event among 'people who stand remote from the stories of Śrī Hari [Vișnu] and the chanting of Viṣnu's praises', including 'women, śūdras, etc.' (BhP 0.6.6). This distinguishes the Bhägavatapurāna from many other works of the Sanskritic archive, especially Vedic texts, which are generally restricted to 'high'-caste males. Letters should be addressed to everyone, inviting them to this 'exceedingly rare congregation of the pious' (BhP 0.6.8). All are invited to 'drink the nectar of the glorious Bhāgavata[purāna]'. Busy people who are unable to attend for the full week are urged to come for at least one day. 
There are explicit instructions for how the site of the saptāh is to be prepared. If the event is held in a private residence, all distracting household items should be cleared away. The ground should be cleaned, swept and plastered with cow-dung. The surface should be decorated with designs made from mineral paints. Five days before the saptāh begins, floor coverings are to be brought for people to sit on. A lofty ceremonial hall or mandapa is to be constructed and covered with an awning (BhP 0.6.14). It should be decorated with banana palms, fruit, flowers, leaves, flags and other adornments. Higher seats should be set up in the front for brahmins and others who 'are free from worldly attachment' (BhP 0.6.16), and an especially excellent seat is to be arranged for the chief exponent (vaktr, BhP 0.6.17).

Great care is to be taken in the selection of a suitable exponent. He should be a brahmin, a devotee of Viṣnu, free from worldly attachment, capable of expounding on the Vedas and other authoritative texts (śāstras), skilled in giving explanations, reliable, and free from desires. Certain types of people are to be avoided: those who are attracted to other traditions, who are excessively interested in women, and who harbour heretical ideas, 'even if they are well educated'. The exponent should be provided with a seconder to help him 'dispel doubts and to enlighten the public'.

The evening before the saptāh begins, the exponent should shave, and in the morning, relieve himself and bathe. He should then undertake his earlymorning prayers, and worship Ganeśa to ensure that all obstacles are removed. He should then worship Viṣnu, Kṛṣna and the text of the Bhāgavatapurāna with incense and lamps. The chief sponsor should then take a vow in the presence of the exponent for his own welfare, to be upheld for the week. Five brahmins should be engaged to chant continuously the twelve-syllable mantra of Vișnu (om namo bhagavate vāsudevāya) to ensure the smooth progress of the saptāh. Having bowed to the brahmins and other devotees of Viṣnu, the sponsor may take his seat. The instructions advise that 'One who concentrates on the narrative with a pure mind, having set aside thoughts of worldly affairs, possessions, money, home and family, will obtain the ultimate reward', i.e., liberation from cyclical existence.

The exponent should begin his exposition at sunrise and should speak in a 'suitably moderated tone' for three-and-a-half watches (prahara), the equivalent of 10-11 hours. There should be a one-hour break at midday, during which devotees should sing songs in praise of Vișnu. It is recommended that only one small meal be eaten each day so that the exposition need not be interrupted by toilet breaks. The instructions suggest that people should fast for the full week, or take a diet of milk and ghee, or fruit and vegetables with just a single type of grain. Sensibly, however, they say that fasting should not be pursued if it will compromise one's ability to concentrate on the exposition.

Those who want to listen to the saptāh should undergo Viṣnudīkșā, that is, a specific consecration for the event. One who has taken this vow must remain 
celibate for the week, should sleep on the floor, and eat off a platter made from leaves. They should avoid pulses, honey, oil, heavy foods and leftovers. They should abstain from negative emotions such as desire, anger, intoxication, etc. They should not speak negatively about the Vedas, Vaișnavas, brahmins, etc., nor should they address a menstruating woman, a member of a 'low' caste, non-Indians (mlecchas), or non-Hindus. If one adheres to these rules, listening to the narration leads to an 'imperishable reward', the equivalent of ten million Vedic sacrifices.

At the end of the seven days, the audience should worship the exponent 'with great devotion'. Blessed food (prasāda), leaves of sacred basil (tulasī) and garlands of flowers should be distributed to the audience. Praises of Viṣnu and Krșna should be sung to the accompaniment of drums and cymbals. There should be cries of 'Victory!' and 'Salutations!', and a conch-shell should be sounded. Money and food should then be distributed to the officiating brahmins and mendicants. Oblations are to be offered into the fire to compensate for any shortcomings in the event.

Finally, at the completion of his vow of listening to the Bhāgavatapurāna for seven days, the sponsor should give the brahmins sweet rice pudding, a gift of gold and a cow. If it is within his means, he should also present a golden bookstand in the shape of a lion, on which he should place a new copy of the text 'written in beautiful letters'. This should all be given to the exponent along with money, clothes, jewellery, sandal-paste, etc. By doing so, the instructions assure us, listening to the Bhāgavatapurāna leads to the accomplishment of the spiritual, sensual, material and liberational goals of life: 'of this there is no doubt'.

This concludes the traditional description of how a saptāh is to be organized. These instructions provide the archetype for the seven-day event. We will now turn to the contemporary case study, after which the two will be compared.

\section{CASE STUDY}

Having identified about 20 different past and future saptāhs, I found one that was in progress during my visit. According to the hoarding, it was to run from 2-7pm, 30 October to 6 November 2009, at the Śrī Rādhā Sneh Bihārī Ashram, Bihārī-purā, Vrindavan. ${ }^{4}$ The exponent was the Honourable Mridul Krishna Saāstrī-jī Mahārāj. Following local practice, I will refer to the exponent as the śāstrī. In this section, I will describe a typical day.

The ashram was a handsome, white, four-storey building, topped with two ornamental pavilions. It was hemmed in on all sides by shops, ramshackle two- and three-storey buildings and wayside shrines under spreading banyan trees.

4. This was a production error. The poster should have read 30 October-5 November.

(c) Equinox Publishing Ltd 2012.

\section{eevinoxonline}




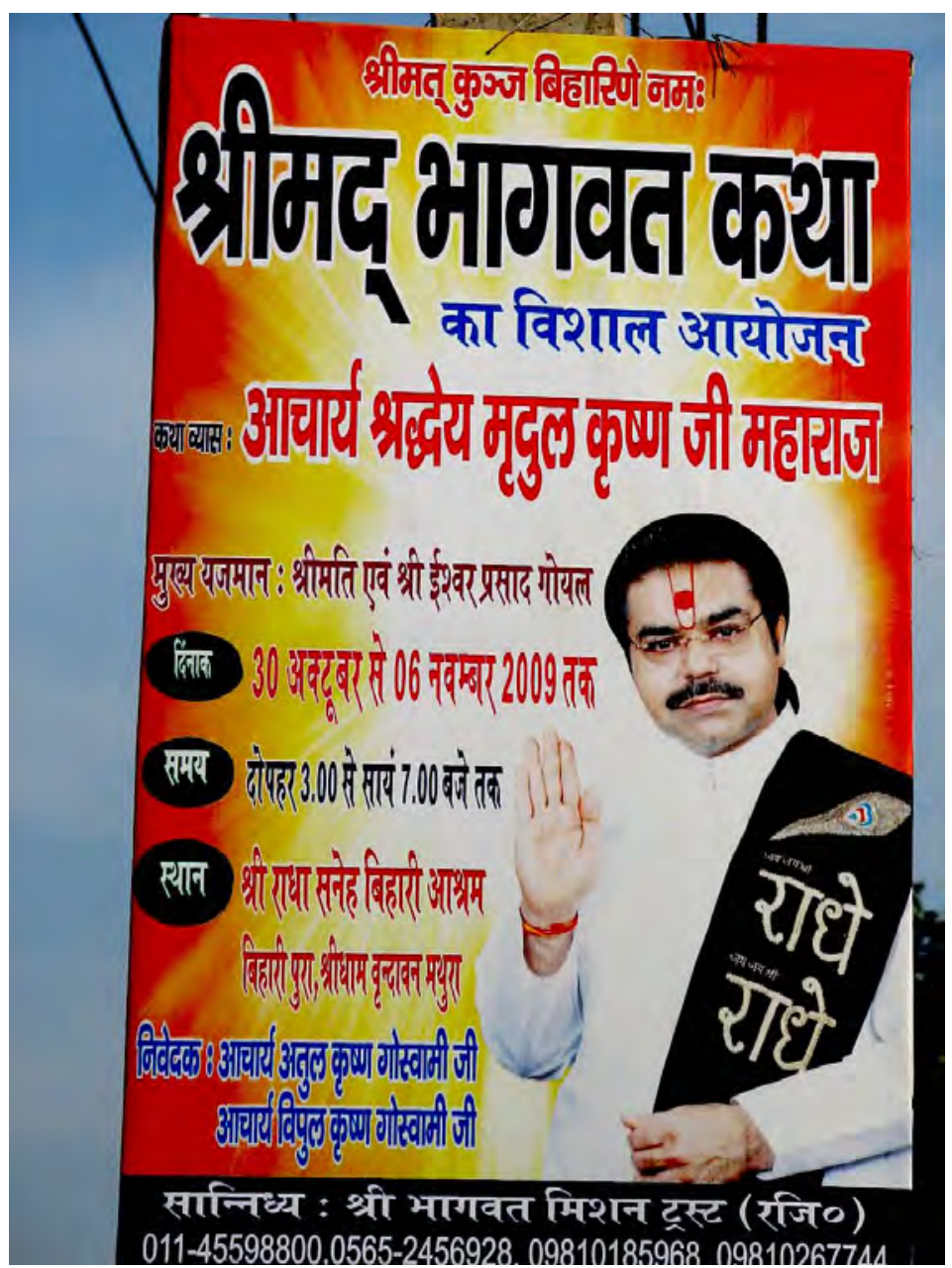

A poster advertising the Vrindāvan saptāh. The words on the black fabric read 'Rādhe Rādhe'

A ceremonial arch of cloth stretched over a timber frame had been erected over the alley beside the ashram, and the street was filled with amplified contemporary devotional music. The alleys around the ashram were spotlessly clean-something of a rarity in an Indian city-and were roofed over with white cotton awnings. Green synthetic carpet had been rolled out in the alleys, and comfortable modern folding chairs lined both sides. Gathered around the entrance were stalls selling garlands of red roses and marigolds, and cheap glistening bangles. A few people were loitering about the entrance. With some trepidation, I left my sandals at the foot of the steps leading into the ashram, rather fearing that I would never see them again. It was a little before $2 \mathrm{pm}$. 


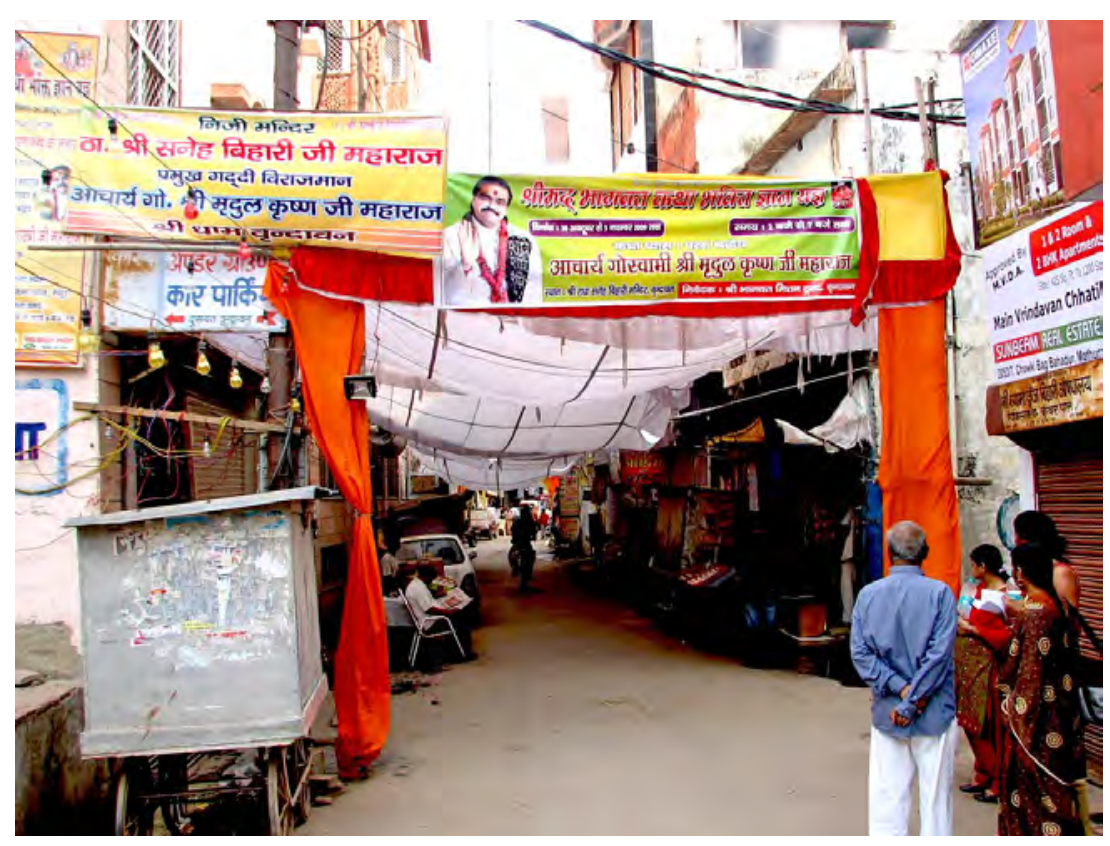

The approach to the Śrī Rādhā Sneh Bihārī ashram, Bihārī-purā, Vrindavan

Stepping into the ashram was like entering another realm: a brilliantly lit dream cavern, part Bollywood fantasy, part disco ballroom, part Hindu temple. Festooned with fairy lights, it was lit by six vast glittering chandeliers, and twenty carbon arc floodlights. Music was being pumped into the hall through four huge speaker boxes. The hall was two storeys high and about $20-25 \mathrm{~m}$ square. On either side were balconies, where in the half-gloom, I could see musicians in white and orange kurtas tuning up, as well as some sound, light and video technicians. The balustrades along the balconies were festooned with bunches of sparkling orange fabric, and with calendar pictures of the young cow-herd Kṛṣna and his lover Rādhā, the cow-herd princess. Wreaths of plastic flowers adorned the pillars and arches. The space below the balconies formed long galleries, at the front of which were large flat-screen TVs where the audience on each side could watch the proceedings on the central stage.

The focal point was the stage at the front of the hall, $8 \mathrm{~m}$ wide and $4 \mathrm{~m}$ high, standing $1.5 \mathrm{~m}$ above the hall floor. It was a shimmering golden fantasy of painted canvas flats depicting a luxurious temple scene, with arches and domes in bold primary colours, draped in garlands of marigolds. In the centre of the stage was a double-panelled silver door, which at this point was firmly closed. Two golden peacocks studded with 'jewels' arched over the central door. On either side were life-size painted images of shaven-headed ascetics in saffron robes. Two more figures of female attendants appeared to be waiting for the doors of the inner sanctum to swing open. The artwork was in a 
naïve but attractive style, with the various flat canvas surfaces set at different depths giving the whole backdrop a three-dimensional appearance. The right-hand half of the stage was filled with a vacant peacock throne. On its left was a sacred tulasī plant in a pot.

The front third of the hall was fenced off with demountable white wooden hurdles and was reserved for invited guests whom I will call VIPs. At this stage, about 30 VIPs were seated on the floor in front of the barrier, about 90 per cent of whom were women. The older and middle-aged women wore gorgeous saris and gold jewellery. Younger women and girls wore salwar-kamiz or Western clothes.

The back part of the hall was open to the public. Here, the audience was growing slowly as people came in and sat down without ceremony on the thin cotton-covered mattresses. Men sat on the right and women on the left, in about equal numbers. Old folk sat on folding chairs around the perimeter of the hall.

Live musicians took over from the recorded music. The hall was filled with the thumping of drums, the ching-ching of cymbals, as well as flute, harmonium, violin and vocals. The devotional music was swaying, rhythmic and hypnotic. Among the audience, heads and bodies swayed; some clapped along quietly with the booming sound while others followed the words in booklets in their laps.

'Rām Rām Rām Sìtā Rām Rām': the music built and accelerated to a throbbing climax, then fell suddenly into total silence. A middle-aged man in a white kurta leapt to his feet and cried 'Jay Jay Śrī Rām-Victory to Rām!', with his hands in the air. We cut to pre-recorded music: 'Śrī Krșnna Hari Murāre', and the crowd began to sway gently again to the music, tapping their fingers in time.

By 3:10pm, the hall was nearly full. There were about 400 people in the back area and 100 VIPs. In the public section, the men were mostly well dressed and appeared to be predominantly lower middle-class. They looked like shopkeepers, owner-drivers, office clerks or school teachers. With the exception of a single young man who was dressed like a rickshaw-walla in a grubby white kurta, dhoti and coloured scarf, I saw no one who looked like a manual labourer or a farmer. There was a scattering of shaven-headed devotees in saffron robes. Half the men sported the single long lock of hair (sikhara) of Krșna devotees, and there were several wild-looking sādhus in white robes.

Four male ceremonial assistants (püjāriss), in spotless white kurtas and dhotis, each with a red scarf, bustled about on the stage. The music dropped and one of the pūjārīs, a middle-aged man who acted as master of ceremonies, made an announcement. We all stood and the exponent entered the stage from the right. Mridul Krishna appeared to be about 50 and wore a gleaming cream-coloured cloak over a dhoti. A handsome man, he was immaculately groomed, slightly heavy, with Bollywood good looks, a round face, black moustache and slicked-back glossy black hair. He wore glasses and a heavy gold watch. He bowed to the red bundle of the Bhägavatapurāna sitting on the 
front of the throne, half hidden beneath garlands of roses and crowned with a coconut. He then bowed before the silver doors in the centre of the stage. ${ }^{5}$

The sponsor of the saptāh, Mr İśvar Prasād Goyal, was a rich merchant from Vrindavan; a tall, thick-set man of 65 or 70 with a powerful, prosperous air. He entered the stage, accompanied by his wife who was a large woman in an orange and gold sari, four middle-aged men, whom I took to be their sons, and three women who looked like the sons' wives. All bowed to the śāstrī, and in pairs performed $\bar{a} r t \bar{l}$ (the offering of lights on a metal tray). The sāastrī led off with a roll-call of names of various deities, to which the audience responded with cries of 'Victory!' while throwing their hands in the air.

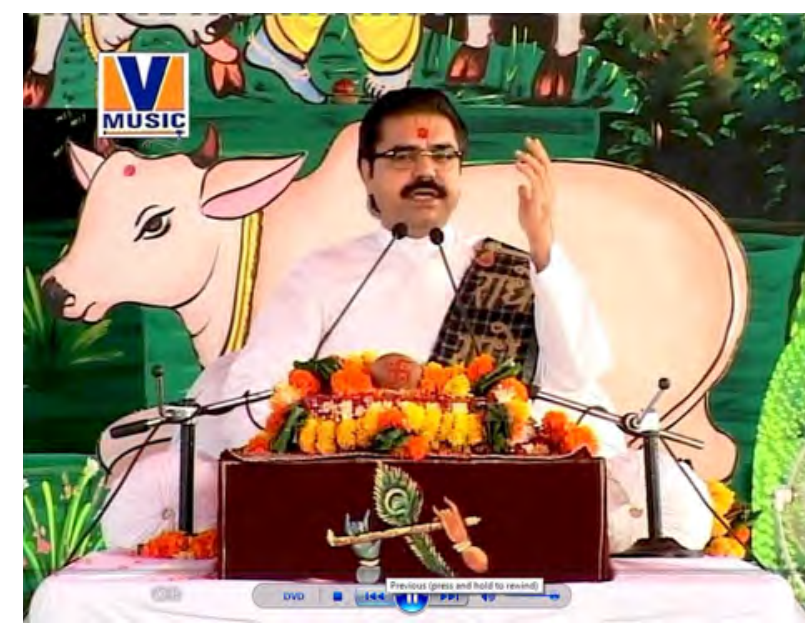

Śāstrī Mridul Krishna as he appears in a DVD of a saptāh in Mumbai, January 2009. The text of the Bhāgavatapurāna sits wreathed in marigolds and is crowned with a coconut as in Vrindavan

The śāstrī momentarily sat in meditation, then slowly began a song of praise to the guru in Sanskrit to the accompaniment of a violin: 'Guru brahmā, guru vișnu...'. He continued to sing in Hindi and sometimes in Sanskrit, accompanied by violin, flute or harmonium.

The śāstrī led in singing, 'Beloved Rādhā, Glorious Rādhā', and as the music swelled, he added 'Beloved Syāma, Syāma, Syāma' in reference to the 'dark' image of Kṛṣna, as the youthful cow-herd. The backing vocalists and the whole audience of around 500 responded. A slight, bird-like village woman with a sun-darkened face and a red and gold sari, her head veiled, stood and gyrated to the music, her eyes closed, smiling inwardly. She clapped her hands above her head in time with the song, 'Rādhe Rādhe ho!' As the beat accelerated, the atmosphere grew electric, and more and more people in the hall were infected by the rhythm. Three or four other members of the crowd began to

5. For more information on Mridul Krishna see http://mridulvrindaban.com/ 
dance and sing along, hands held aloft, including a fat, beaming businessman in a blue checked shirt and grey slacks, his expression blissful. Six, eight, ten women leapt to their feet and danced facing the stage, hands in the air, swinging from side to side in time with the irresistible drum beats. The rhythm was now so profound and insistent that I could feel it reverberating in my chest. All the time, above all the other sounds, the flute, the favourite instrument of Krșna, could be heard. The dancing was sensuous and abandoned, yet each woman seemed to be dancing in her own world-as if in the forests of Vraj.

The rhythm accelerated again, and now most of the crowd were on their feet. Two girls in the VIP section spun one another in circles. The music sped to a climax, and the atmosphere became ecstatic. Too fast to clap, too fast to sing along, the śāstrī maintained his call of 'Jay! Rādhe Rādhe Rādhe!' The melody moved upscale in semitones. The tempo hit 120 beats per minute. The music climaxed-then snapped into total silence. A slow release followed, as the tension drained away, and the audience placed their hands in añjali as if in prayer.

Calm returned as everyone returned to their seats on the floor. It was now 4pm and the śāstrī began the story of Mt Govardhan-how Kṛ̣ṇa lifted the mountain with just one hand to provide shelter from a terrible storm for the people of Vraj. Speaking in Hindi with just the occasional line of Sanskrit, he was accompanied by a violin. In the quiet hall the audience listened attentively. Whenever the saastrī sensed the audience's attention drifting, he punctuated his discourse with cries of 'Bhagavān kī...', to which the audience would respond 'Jay!' ('Victory to the Lord!'), throwing their hands in the air.

The śâstrī spoke in clear, highly Sanskritic śuddh ('pure') Hindi. In all the time I attended, I heard no Persian or Arabic terms, and only a handful of English words.

To the accompaniment of a flute, the saastrī spoke of the love of the cow-herd girls-the gopis-for Krșna. Sometimes he spoke with rising passion to make a point, and the audience would clap a little. He asked, 'What can give us peace?' and told a story about how fish cannot live without water. The saasstrī seemed to be extemporising-he certainly never referred to the Sanskrit text on the front of the throne, which remained firmly wrapped in its crimson and gold cover, but he may have referred to a set of notes which he took from a red shoulder bag when he first sat down, and which might now have been lying in his lap.

The śāstrī spoke on, his eyes closed. From time to time he raised one hand for emphasis, or occasionally two. The music began to swell again-flute, bells and harmonium played while the drums thumped incessantly. The audience began to clap. Ten women in the central area leapt up to dance, swaying from side to side while singing along. The hall was packed and the temperature was rising. Two young men with agricultural backpack sprayers wove their way around the hall spraying the crowd with rose-scented water. The birdlike village woman danced coquettishly with eyes closed, smiling to herself. The śāstrī led a call of 'śrī Rādhe!', and the audience roared back. Young girls danced energetically in the 'mosh pit' of the VIP area. Older women swayed

(c) Equinox Publishing Ltd 2012.

\section{eøuinoxonline}


their broad hips and clapped, arms aloft, palms forward as if for darśan. The music built to a colossal climax and suddenly dropped dead again.

The śāstrī resumed his discourse without missing a beat. He repeated a famous verse from the Gītā ('Whenever obstacles to dharma appear...', Bhagavadgita 4.7) and some of the crowd joined in. Again he spoke of Krșna and the gopis in Vrindavan. By this point, he had talked and/or sung for two hours without a break, yet remained as fresh, composed and engaging as ever. There was not a single wasted word or gesture in his magisterial delivery.

By 5:30pm we needed another round or two of 'Śrī Rādhe!' to reinvigorate us. The śāstrī was speaking of love (prem), and gave the example of Hanuman's love for Rām. This pattern of quiet discourse, interspersed with call and response, leading up to more bouts of wild dancing lasting up to 20 minutes, was repeated throughout the afternoon and evening.

At 7:35pm a young female actor in a brown sari with a red dupatta and a tall gold crown appeared on the stage. This was Rukmin̄ī Kṛșna's bride-to-be. She had two attendants in pink and blue saris. The three danced on the lefthand side of the stage as the saāstrī sang and the audience clapped. The actors looked like amateurs-this was the first and only time in the entire 'performance' where the level was less than professional. I wondered if they were members of the sponsor's family. 'Rukmini $\overrightarrow{1}$ had trouble keeping up with the music. Suddenly, an actor playing Krșna rushed on to the scene from the right and 'pursued' Rukmin̄ī round and round the stage, eventually 'capturing' her. The drama was now only a notch or two above pantomime.

The master of ceremonies reappeared and placed garlands around the couple's necks and chanted some verses in Sanskrit. The pair exchanged garlands as in a wedding ceremony and flowers were thrown over them. At this point the sponsor and his family appeared on stage and presented gifts of clothes and trays of sweets to 'Kṛșna' and 'Rukmiṇì' and performed ārtī to them and to the śāstrī. Calls and responses of 'Jay ho!' filled the hall. The MC led a rendition of the well-known Sanskrit prayer, 'Tvam eva...', while assistants helped the śāstrī arrange his possessions. The sponsor's family made offerings to the śāstrī, while members of the audience performed half- or full-body prostrations facing the stage, then drifted towards the door. It was now 8:00pm, and piped sacred music replaced the live musicians. The crowd began to thin. The family gave gifts to the śāstrī, who blessed them in return by placing his hand on their heads. He rose from his throne, bowed to the bundled-up purāna, and approached the image of Kṛșna inside the silver doors. A curtain closed behind him, and he was gone.

The floodlights were dimmed while prasād (blessed food in the form of sweet deep-fried pellets of yellow batter) was distributed from the VIP section to the public. The hall emptied as the piped music blared on. Finally, the sound cut out, and the lights went down as I left the hall. Outside in the alley, my sandals were, much to my relief, still very close to where I had left them six hours earlier. 


\section{CONTINUITIES}

The archetypal description of a saptāh and the contemporary case study described above may be separated by as much as a thousand years, but there are many points of continuity between them. The Sanskrit text of the Bhāgavatapurāna as an artefact is obviously of central importance to the archetypal saptāh: 'This text, known as the Glorious Bhāgavatapurāna, is Kṛșna himself in manifest form' (BhP 0.1.30). The instructions explicitly declare that it is an important focus of worship. What is the role of the text in the contemporary saptāh events?

The DVDs of Mridul Krishna's huge saptāh in Mumbai have excellent closeup footage of the text in the preliminary rituals. When it first appeared, it was tightly wrapped in crimson brocade, bound in golden tape, and crowned with red rose petals and marigolds. The saāstrī and a pūjārī honoured the text with a tray of flowers, fruit, water, and kumkum powder. Finally, the sāastrī performed ārtī to the text. The śāstrī and the pūjārī then placed the text on the head of the sponsor, while a pitcher (kalaś) was placed on the head of his wife. They all left in procession for the venue of the saptäh; the sponsor and his wife walking in front with the text and kalash on their heads, while the saastrī followed in a garlanded silver carriage drawn by two white horses. At the saptāh venue, the pūjāri placed the text on the altar and the kalash on a shelf below it. The sponsor then garlanded the text with red and white flowers. The text was then crowned with marigolds and a coconut on which a red swastika with four dots had been painted. The sponsor and his wife performed ārtī to it, and at the end of a series of Sanskrit invocations, the entire official party of about 20 placed flowers on it.

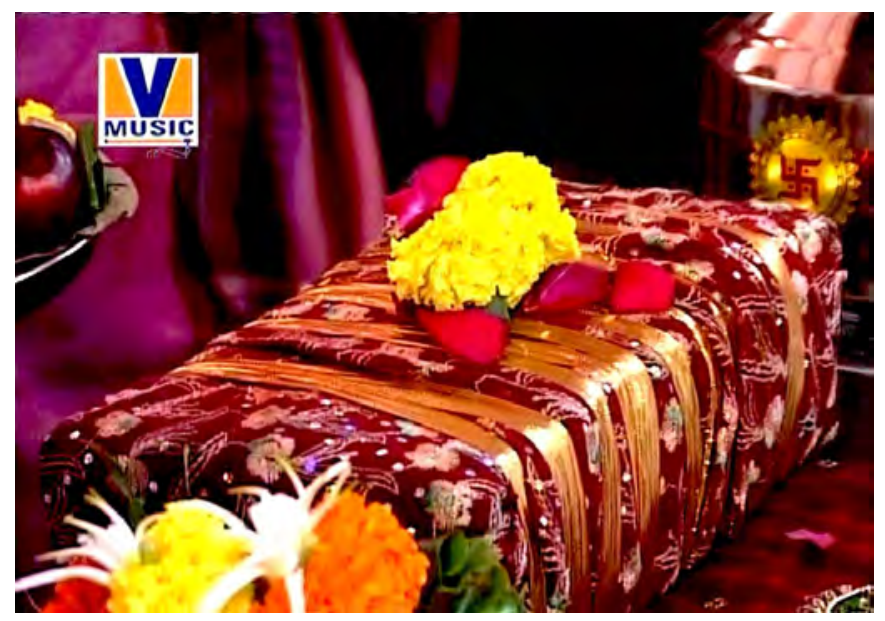

The text of the Bhāgavatapurāna wrapped in brocade and gold tape at the Mumbai saptāh. Source: Vipul Music Co.

(C) Equinox Publishing Ltd 2012.

\section{eøuinoxonline}


Moving from the role of the text itself to the role of Sanskrit, how are we to understand the place of the sacred language in the archetypal saptāh? Sanskrit has long been the language of the educated, literary and spiritual elite (Pollock 2006). The archetypal saptāh may have been conducted in Sanskrit, as it was an 'exceedingly rare congregation of the pious'. The exponent may have read verses in Sanskrit and perhaps explained them in simple spoken Sanskrit, occasionally with the assistance of his seconder. (There is, however, one good argument in favour of the archetype being conducted at least partly in the vernacular to which I will return below.) Irrespective of whether the entire saptāh was conducted in Sanskrit, we can assume that Sanskrit played a central if not an exclusive role.

The śāstrī at Vrindavan made extensive use of Sanskrit quotations from the Bhāgavatapurāna. Sanskrit verses were used at crucial points in the narrative, where they served to add emphasis, beauty, dignity or authority to a particular passage, as they tied the spoken discourse directly back to the authority of the original text.

On the basis of this evidence I suggest that the centrality of the text of the Bhägavatapurāna as a focus of worship and the significance of the Sanskrit language are important points of continuity between the archetype and contemporary practice.

The original instructions advised that an astrologer should be invited to determine an auspicious day on which to begin the saptāh, and that the Indian months covering the period from August to November and June to July were considered most suitable. I noted 19 advertisements for saptāh events in Vrindavan and one in Uttarkashi. The starting dates were as follows:

\begin{tabular}{|l|c|c|c|c|c|c|c|c|c|c|c|c|}
\hline Month & Jan & Feb & Mar & Apr & May & Jun & Jul & Aug & Sep & Oct & Nov & Dec \\
\hline No. & 0 & 1 & 0 & 1 & 1 & 0 & 1 & 1 & 2 & 10 & 2 & 1 \\
\hline
\end{tabular}

Starting dates for 15 events fell between August and November, which tallies well with the statement in the archetype. However, June to July (Śrāvana) appears to have fallen from favour as an appropriate time.

The instructions for the archetype suggest that the sponsor set aside as much money for a saptāh as he would for a wedding. One informant suggested that the minimum cost for staging a saptāh in Vrindavan is in the range of US\$10,000-15,000, and 'it goes up from there'. This still reflects the cost of an average middle-class wedding. Mridul Krishna's saptāh in Mumbai with tens of thousands of participants (not to mention the five elephants in the procession) must have been very expensive indeed. Pilot Baba, a well-known holy man with an ashram near Uttarkashi, was rumoured to have received 10 crores of rupees (US\$2 million) plus a helicopter for his role in a saptāh.

The news that a saptāh is to be held 'should be made known everywhere', declare the instructions for the archetype. The intensive advertising of saptāh events in Vrindavan provides an eloquent expression of this principle in the 
contemporary context. Nearly all of the posters included pictures of the main exponent. One surprising feature is that very few of the exponents resembled the traditional image of the Indian holy man: flowing locks, grizzled beard, saffron robes and strings of beads. As few as one quarter of the exponents depicted in the posters fitted this description. One or two had boyish, saintly appearances, and were clean-shaven, but with shoulder-length hair or longer. The great majority, however, sported what I would call Bollywood good looks: they were depicted as being of very fair complexion, handsome, and tending towards the plump. Most had moustaches and were perfectly groomed. They had a prosperous middle-class look about them, and perhaps represented and indeed appealed to a middle-class demographic.

The archetype states that the site of a saptāh should be decorated with leaves, flowers, fruit, trunks of banana palms and flags. The above 'thick description' of the saptāh at Vrindavan has provided some idea of the profusion of decorations at that venue. Even if over time the nature of the decorations has changed (now it is fairy lights and plastic flowers), the intention and motivation, which are perhaps basic to many societies in India and beyond, remain unchanged: the site of any sacred event is to be made as beautiful as possible with the materials available.

The archetypal instructions state that 'Women, sūdras and others who stand remote from stories of Vișnu' may be invited. This inclusivity is an important distinction between what we might call 'purāṇic religion' and Vedic traditions. As mentioned above, Vedic rituals were restricted to the 'twice-born' varnas and generally to males. In fact terrible punishments are prescribed for non-brahmins who happened to hear Vedic recitations.

What can be said about gender, caste and class in relation to contemporary saptāhs? Firstly, women made up at least half of the audience in all the events I witnessed, except the Mumbai saptāh where they accounted for at least 90 per cent of participants. The Vrindavan saptāh was in theory open to the public. In practice, however, the audience seemed to be self-selecting in terms of class, and probably caste as well. As noted above, it appeared to be a lower middle-class demographic. With a single exception, I did not see anyone who looked like a manual labourer or who was obviously of a 'lower' caste. I suggest that the opulence of the interior and perhaps the presence of security staff may have functioned as a barrier or a filter.

Having surveyed the major points of continuity between the archetype and the case study, we will now turn to the major points of divergence.

\section{DIVERGENCES}

Two major points of divergence between the archetype and the case study will be discussed below: the significance of sectarian content, specifically the role of Kṛ̣na's consort Rādhā, and the predominance of the vernacular language.

(C) Equinox Publishing Ltd 2012.

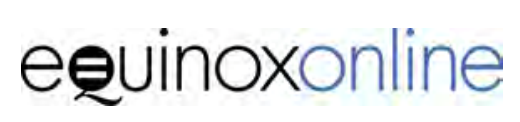


One of the clearest abiding impressions of the Vrindavan saptāh was the centrality of the figure of Rādhā. Within the Nimbārka and Gaudīya traditions of Vaiṣnava worship, Rādhā is said to be Kṛṣna's principal consort. The divine couple constitute the highest objects of worship (Schweig 2007a). Rādhā first appeared from about the twelfth century CE onwards, and this tradition strengthened under Caitanya (1486-1533). Within these lineages, her yearning for Krșna is regarded as the purest form of love for the Divine, and is a model for human emulation. Worship of Rādhā, which is particularly strong in Vrindavan, seems to overshadow that of Kṛșna himself (Chandra 1998: 259).

Mridul Krishna's presentation of stories from the Bhägavatapurāna did not particularly stress the role or importance of Rādhā, but she was an everpresent and central element in the delivery of those stories. There are seven aspects in which the centrality of Rādhā may be described:

1. The ashram in which the saptāh was held was called the Śrī Rādhā Sneh Bihārī Ashram, located in the part of Vrindavan known as Bihārī-purā, 'The City of Bihārī'. The word bihārī (Sanskrit: vihārī) means literally 'one who wanders about for pleasure' or 'the sportive one'. It refers specifically to Krșna as the cow-herd who enjoys love-games with the gopis of Vrindavan, of whom Rādhā was the foremost. 'Rādhā Sneh' is Hindized Sanskrit meaning 'beloved of Rādhā'. Thus both the name of the ashram and even its location give a clear indication of the sectarian inclination of the saptāh itself.

2. The central image in the ashram, the glassy black figure which stood behind the silver doors, is also this form of Kṛ̣nna, Ban̉ke Bihārī, playing his flute with the devoted Rādhā pressed to his side.

3. A great number of the kirtans (songs of praise), either sung by the śāstrī, or those which he led and to which the audience responded, were directed primarily to Rādhā. For example, commonly used kīrtans had the main refrain 'Beloved Rādhā, Glorious Rādhā' or 'Victory to Rādhā, Rādhā, Rādhā!'

4. The śāstrī frequently broke up his narratives with a call to the audience, to which they would respond enthusiastically, 'Śrī Rādhe Rādhe'. With each call, the audience would throw their hands in the air with palms facing the front as if receiving darśan.

5. Most of the images and posters around the walls of the hall depicted Rādhā alone or with her celestial lover. The visual presence of the favoured gopi complemented her presence in the discourse, song and call-and-response episodes.

6. Observing the women and girls dancing in an uninhibited manner, especially the younger women in the VIP section, it was easy to imagine that they had been transported to the mythic forests of Vrindavan and were dancing with 'the sportive one' themselves. More than once, women stood up in the audience, and in a semi-ecstatic state, opened their arms 
in the direction of the image of Baṅke Bihārī, as if inviting a lover into their embrace.

7. The main contemporary devotional song, which was played over the PA and piped into the streets surrounding the ashram, was a celebration of Rādhā, entitled 'Rādhā nām sañg-Braj caurāsī kos yātrā', performed by Gaurav Krishna, Mridul Krishna's son. This was a popular new release and was on sale widely in North India.

Having spent these days at the Vrindavan saptāh where the air was thick with Rādhā-even the śāstri's black scarf was emblazoned with her nameI was surprised to be reminded that she is not actually mentioned in the Bhāgavatapurāna. It is true that in BhP 10.30, Kṛșna disappears into the forest for a tryst with a favoured lover, but she is not named. It appears that Rādhā is a later invention and has been interpolated into the dominant narrative. It was a great revelation to discover that Rādhā, who in many respects was the 'star' of the saptāh, is absent from the very text on which the entire event was supposed to be based.

I outlined above the reasons for believing that the archetypal saptāh may have been conducted at least in part in Sanskrit. This rests on the fact that Sanskrit was the usual medium for elite religious discourse. The main objection involves the participation of women and people of 'low' castes. It is widely believed that such individuals did not understand Sanskrit. There are therefore three possibilities: first, that the discourse was delivered entirely in a vernacular for their benefit; second, that the discourse was in vernacular, but with a smattering of Sanskrit verses, as is the case today; and third, that the discourse was delivered primarily in Sanskrit. In this case, the assumption would be that they would benefit simply from being in its presence. The belief in the power and efficacy of sacred sound, with meaning as a poor cousin, is common and widespread in Hindu communities even today. Further, the idea that one must be able to understand the sacred word in order to benefit from it is perhaps an Orientalist habit of mind with roots in the Protestant traditions of Europe.

The intentions of the authors of the archetype are ultimately unknowable. In any case, the contemporary saptāh is certainly conducted in śuddh Hindi. The reason for this choice of register is obvious. The saptāh is conducted in a traditional and deeply religious context. The traditional nature of the discourse means that English loanwords, which usually characterize modern, globalized, urban Hindi, are inappropriate. Arabic, Persian and Turkish vocabularies, which add a distinctly Islamic flavour to the register, would of course be inappropriate in such a specifically Hindu context. Taking all this together, I suggest that the striking predominance of the vernacular over the sacred language of Sanskrit represents the second significant divergence.

I will conclude this section by noting a number of minor points on which the case study diverges from the archetype. The archetype makes no mention 
of musicians, but the śāstrīs were accompanied by harmonium, flute and/or mrrdanga in all the contemporary saptāhs I witnessed. The role of religious ecstasy in the contemporary event seems to be lacking from the archetype, which I envisage as a rather sombre affair. The archetype specifies an early start, followed by 10-11 hours of discourse per day. All the contemporary saptähs that I observed were half-day events and ran in the afternoon and early evening only. According to the archetype, five brahmins should continually chant the name of Vișnu during the saptāh to ward off interruptions, but this does not appear to be current practice. The kalaśasthāpana (placing of the pitcher), which was part of the Vrindavan and Mumbai events, also appears to be an innovation. The dramatic performance depicting Kṛșna's marriage is not mentioned in the archetype and may be a modern innovation.

Having considered the main continuities and points of divergence between the archetype and the case studies, we will now examine both continuity and divergence in the light of modernizing processes in the concluding section.

\section{CONCLUSION}

Modernity has exposed the practice of the saptāh to a raft of new ideologies and technologies. Many of the phenomena described above-both the continuities with, and divergences from, the archetype-can be explored in terms of modernizing influences. These might be seen as either resilience in the face of such processes, or as adoption of contemporary technological innovation. The relationship between continuity and divergence on the one hand, and resistance or assimilation on the other may be expressed in the following table:

\begin{tabular}{|l|l|l|}
\cline { 2 - 3 } \multicolumn{1}{c|}{} & In spite of modernity/technology & Because of modernity/technology \\
\hline $\begin{array}{l}\text { Continuity with } \\
\text { archetype }\end{array}$ & $\begin{array}{l}\text { - Centrality of BhP text and Sanskrit } \\
\text { - Determination of time and date }\end{array}$ & $\begin{array}{l}\text { - Decorations } \\
\text { - Adoption of contemporary } \\
\text { products and technologies } \\
\text { - Extended publicity, websites, } \\
\text { YouTube }\end{array}$ \\
\hline $\begin{array}{l}\text { Divergence from } \\
\text { archetype }\end{array}$ & & $\begin{array}{l}\text { - Use of vernacular } \\
\text { - Advertising posters, sound } \\
\text { systems, DVDs, music }\end{array}$ \\
& & $\begin{array}{l}\text { Shorter hours } \\
\text { - Middle-class sponsors }\end{array}$ \\
\hline
\end{tabular}

Three aspects of continuity persist in spite of modernity. First, there has been a long historical decline in Sanskrit education and literacy, especially with the rise of English as the language of the educated elite. Today, the Bhāgavatapurāna and Sanskrit in general are only intelligible to a tiny fraction of the population. As a result, the function of both the text and the Sanskrit language has 
shifted since the archetype was first envisioned. They are not so much sources of knowledge or the medium of knowledge transfer, but have become symbolic sources of authority and power. Both now fulfil a more ritualized function. In spite of the impacts of modernity, the text of the Bhägavatapurāna and the use of Sanskrit remain central to the saptäh, though in an altered, symbolic form. Secondly, global scientific epistemologies have failed to dislodge indigenous knowledge systems, such as astrology, which remain particularly lively in India. Given this, it is little surprise that the dates of the saptāh are still determined by astrological specialists. Similarly, the traditional Ayurvedic system which determines the conduct of the chief sponsor during the saptäh (the maintenance of a pure, sāttvik diet, conservation of energy (tejas) through sexual abstinence, etc.) remains forceful. Thirdly, much of the decoration of the site of the kathā remains highly traditional: the garlands of marigolds, flags and fruits.

Turning now to continuities enabled by modernity, firstly, the visual presentation of the venue has also been enabled and enhanced by modernity. A wide range of contemporary industrial products has been adapted to traditional usage, for example, garlands of plastic flowers now hang alongside traditional wreaths of yellow and orange marigolds. Secondly, the authors of the archetype understood the importance of publicity and explicitly stated that word of a saptāh 'should be sent to all places'. The advent of the Internet has greatly expanded the possibilities for diffusion of Bhāgavata narratives and saptāh events. As mentioned earlier, Google gives tens of thousands of hits for 'Bhagwat puran saptah', and hundreds of saptāhs are available on YouTube.

Many of the most obvious divergences from the archetype are the result of the impacts of long-term societal change, partly if not exclusively the result of modernity. First, a decline in the use of Sanskrit means that the contemporary saptāh is conducted in Hindi as the practical language of communication, while Sanskrit is reserved for ritual and symbolic functions. Secondly, the widespread use of information and communication technologies has enabled the evolution of a genre of saptāh events that would be barely recognizable to the authors of the archetype: the laser-printed hoardings, the booming PA systems and the glittering halls. Other social changes mean that few would have the luxury of being able to spend 10-11 hours listening to the narration for seven days on end, with the result that the contemporary saptäh typically runs from $1-4 \mathrm{pm}$. Finally, the globalization of the Indian economy has spurred the emergence of wealthy middle class, which now has the means and the inclination to sponsor saptähs on an unprecedented scale, costing millions of dollars.

Thus the saptāh, like cultural and social practices everywhere, is increasingly enmeshed in a web of modernizing processes. Some of these processes are forcing or enabling change; others are enabling or enhancing continuity with traditional practice. No matter how far the contemporary practice diverges from the archetype, the saptāh seem likely to continue to be a recog-

(c) Equinox Publishing Ltd 2012.

\section{eøuinoxonline}


nized, time-honoured, sacred shell into which sectarian and/or local content can be incorporated to give that content legitimacy, credibility and power. It will continue to be the means by which sponsors express and demonstrate their piety and munificence, and by which they continue to accumulate social capital by providing the community with opportunities for spiritual edification, communion with the divine and entertainment. They will continue because, as one informant put it, 'Saptāhs make everyone happy'.

\section{ABBREVIATIONS}

BhP Bhāgavata Purāna Goswami, C. L. (ed). Śrīmad Bhāgavata Mahāpurāna (with Sanskrit Text and English Translation). 2 vols. Gorakhpur: Gita Press, 2005.

H. Hindi

Skt. Sanskrit

\section{REFERENCES}

Bryant, E. F. 2004. Krishna: The Beautiful Legend of God. New York: Penguin Books.

- 2007. 'Krishna in the Tenth Book of the Bhagavata Purana.' In E. F. Bryant (ed.), Krishna: A Sourcebook: 111-36. Oxford: Oxford University Press.

Chandra, S. 1998. Encyclopaedia of Hindu Gods and Goddesses. New Delhi: Sarup and Sons.

Pollock, S. 2006. The Language of the Gods in the World of Men: Sanskrit, Culture, and Power in Premodern India. Berkeley: University of California Press.

Rocher, L. 1986. The Purānas. Wiesbaden: Harrassowitz.

Schweig, G. M. 2007a. 'The Divine Feminine in the Theology of Krishna.' In E. F. Bryant (ed.), Krishna: A Sourcebook: 441-74. Oxford: Oxford University Press.

- 2007b. Dance of Divine Love: The Rāsa Lïlā of Krishna from the Bhāgavata Purāna, India's Classic Sacred Love Story. Delhi, Motilal Banarsidass [orig. pub. Princeton, 2005].

Spradley, J. 1980. Participant Observation. New York: Holt, Rinehart and Winston. 